\title{
STABLE ISOTOPE TREE-RING DATES: LIST 1
}

Loader, N.J., McCarroll, D., Young, G.H.F., Davies, D. and James, J.G., (Department of Geography, Swansea University, Singleton Park, Swansea SA2 8PP, UK)

Miles, D. and Bronk Ramsey, C. (Research Laboratory for Archaeology, Oxford University, 1 South

Parks Road, Oxford, OX1 3QY, UK.)

\section{Introduction}

Recent developments in UK dendrochronology have shown that cross-dating of annuallyresolved tree-ring stable isotope sequences from oak latewood cellulose provides an extremely effective precision dating method. We report the first date list for stable isotope dated timbers. The isotope dating method is outlined below and is detailed in Loader et al. (2019).

\section{Overview}

The oxygen isotopic signal preserved within the latewood of tree rings primarily reflects the isotopic composition of the precipitation sampled by the tree during summer growth. Unlike ringwidth dendrochronology, trees do not need to be physiologically stressed to record a dating signal and so isotope dating, the statistical matching of an undated isotope timeseries with a reference chronology, works well in temperate, low climate-stress regions where trees may exhibit rapid growth or limited year-to-year variability in their ring widths.

The stable oxygen isotope data conform to a Student's $t$ distribution, so unlike ring-width dendrochronology it is possible to assign a statistical probability to the resulting date; the BailliePilcher, BP-t-value is not appropriate for use with isotope data. After cross-dating, the strength of potential dates is assessed. When a sample does not produce a match that satisfies the two objective criteria (match probability $1 / \mathrm{p} \geq 100$, and uniqueness of match or "isolation factor" $\geq 100$ ) then it is considered undated. When a match passes the thresholds, it is not necessarily accepted as a firm date. Fortuitously high correlation coefficients are possible and it is necessary to consider whether the date is consistent with other evidence (Historic England 1998). If multiple samples are available these may be combined, as in ring-width dendrochronology into a local site chronology for dating. Where a date is assigned, the felling date or range is determined taking into account any rings not measured isotopically and the presence and completeness of the sapwood, following criteria identical to ringwidth dendrochronology (English Heritage 1998, Miles 2006, Loader et al. 2019, Miles et al. this volume).

\section{Information reported}

Each entry includes: the type of sample, the final measured ring date and sapwood complement, the Student's $t$-value and the probability (1/p) of the match (corrected for filtering, autocorrelation and resampling); the total number of rings $(\mathrm{N})$ and the number of rings measured isotopically $(\mathrm{Ni})(\mathrm{N} / \mathrm{Ni})$; the sample code. All the timbers have been dated against the Central England Master chronology developed by Loader et al. (2019), or from site masters derived from this. Details are then given for any samples dated by ring-width cross-matching (with Baillie-Pilcher $t$-values). For estimated felling date ranges, unless otherwise stated, the $95 \%$ confidence limits for the number of sapwood rings are from Miles 2006. Dates refined using OxCal are given in italics, indicating that they are interpretative 
dates. A complete statistical report is available from the first author upon request, citing the laboratory sample code (e.g. SWAN009).

\section{Bibliography:}

English Heritage, (1998) Dendrochronology: Guidelines on producing and interpreting dendrochronological dates, London.

Loader, N.J., McCarroll, D., Miles, D., Young, G.H.F., Davies, D., Bronk Ramsey, C. (2019) 'Tree Ring Dating Using Oxygen Isotopes: A Master Chronology for Central England', Journal of Quaternary Science. (Open access: https://onlinelibrary.wiley.com/doi/full/10.1002/iqs.3115, accessed 2/8/19)

Miles, D.H., (1997) The interpretation, presentation, and use of tree-ring dates, Vernacular Architecture, 28, 40-56.

Miles, D.H., (2006) Refinements in the Interpretation of Tree-Ring Dates for Oak Building Timbers in England and Wales, Vernacular Architecture, 37, 84-96.

Miles, D., Loader, N.J., Young, G.H.F., McCarroll, D., Davies, D., Bronk Ramsey, C., James J.G. (2019) 'Stable isotope dating of historic buildings' (this volume). 


\section{ENGLAND}

\section{GLOUCESTERSHIRE}

1. Yate, Goosegreen Farmhouse (ST 711 838)

Felling date: Winter c. 1607/8

Purlin 1607(c.16C): $t=7.68$, N/Ni 65/51, 1/p >1 million [SWAN009]

This early seventeenth century farmhouse with contemporary wall paintings failed to date through dendrochronology. See Loader et al. (2019) and Miles et al. (this volume) for further details of the building and the dating.

$$
\text { (For an image of this building, see Figure I-5, p. xx.) }
$$

\section{HAMPSHIRE}

2. Sherborne St John, The Vyne. (SU 636 568) Portico

Felling date: Winter 1655/6

Principal rafters: (1) 1655(22C): $t=6.42$, N/Ni 73/73, 1/p>121k [SWAN020]; (2) 1655(18C): $t=5.84, \mathrm{~N} / \mathrm{Ni}$ 86/86, 1/p $>18 \mathrm{k}$ [SWAN007]

Dendrochronology carried out over 20 years ago failed to date the portico. Isotope dating has identified this as the earliest portico on an English country house. See Loader et al. (2019) and Miles et al. (this volume) for further details of the dating.

$$
\text { (For an image of this building, see Figure I-4, p. xx.) }
$$

\section{NORFOLK}

3. Wymondham, 9 Town Green (TG 109 018) 
This appears to be the earliest known example of a two-storeyed three-cell planned house with a fireplace at the upper end of the hall. This plan has been identified as the dominant form for rural yeoman houses throughout south and east England by c.1600, but appears to have originated in North-East Suffolk, where it is popular by about 1530. The roof is of raised-aisle form. The building contains in important sequence of 16th and 17th-century painted schemes. Building information from Philip Aitken, cores kindly provided by Martin Bridge

$$
\text { (For an image of this building, see Figure I-9, p. xx.) }
$$

\section{OXFORDSHIRE}

4. Mapledurham, Tinkers Green, Well Cottage, (SU 689 781)

Felling date: Winter 1804/5

Mantel beam (beech) 1804(C): $t=7.0, \mathrm{~N} / \mathrm{Ni} 60 / 60,1 / \mathrm{p}>270 \mathrm{k}$ [SWAN026].

A generic vernacular cottage, as found on the Mapledurham Estate, the walls are of half brick thickness with pilasters, supporting an elm or poplar wall plate. The first floor joists are of poplar and the roof timbers of non-oak species unsuitable for dendrochronology. It was thought that the cottage dated from the late eighteenth or early nineteenth centuries, and the date derived from the severed end of a beech mantel beam has given a precise date to this structure. See Miles et al. (this volume) for further details of the dating.

(For an image of this building, see Figure I-8, p. xx.)

5. $\quad$ Oxford, Lincoln College Chapel, (SP 514 063), Chapel Roof

Felling date: Spring 1627

Principal rafter 1627(111/4C): $t=8.70, \mathrm{~N} / \mathrm{Ni}$ 97/98, 1/p>1 million [SWAN029].

Of ten samples previously taken from the roof of the Chapel, one failed to date. This has now been dated and shown to be contemporary with the rest of the roof structure. See Loader et al. (2019) and Miles et al. (this volume) for further details of the dating.

\section{SHROPSHIRE}

6. Moreton Say, Oldfields Farm, (SJ 629 364).

Felling date: Winter 1393/4

Arcade post (1) 1368: $t=7.10$, N/Ni 100/86, 1/p>1 million [SWAN004]; (2) 1393(17C), ring-width cross-matched with the isotope-dated sample (BP- $t=6.04,56$ ring overlap) 
This base cruck hall was sampled in 1995 but only the later phase dated (Miles and Haddon-Reece 1994, VA 25, list 56). Two samples were taken from the arcade post; the longer one with incomplete sapwood was dated by isotope analysis. A second sample with bark edge crossmatched with this to give the precise felling date. See Loader et al. (2019) and Miles et al. (this volume) for further details of the building and the dating.

(For an image of this building, see Figure I-3, p. xx.)

\section{WARWICKSHIRE}

7. Aston Cantlow, Wilmcote, 4 Old School Lane, 'Cruck Cottage’ (SP 164 579), Cruck range

Felling date: Spring/summer 1372

Cruck 1371(161/4C): $t=6.8$, N/Ni 66/62, 1/p $>300 \mathrm{k}$ [SWAN010].

The cruck range is now split into three houses with a later crosswing (dated to 1522-55, VA 48, 115). See Miles et al. (this volume) for further details of the building and the dating.

(For an image of this building, see Figure I-6, p. xx.)

8. Loxley, Loxley Farm. (SP 256 530)

Felling date: Winter 1419/20

Saddle 1419(12C): $t=6$., N/Ni 67/67, 1/p>17k [SWAN028]; Purlin 1414(20): $t=5.4 ; 64 / 63,1 / \mathrm{p}=1481$ [SWAN027].

A smoke-blackened hall house described in Alcock and Miles 2013 (LOX-A); see also Miles et al. (this volume) for further details of the building and the dating.

(For an image of this building, see Figure I-7, p. xx.)

\section{WALES}

BRECONSHIRE

9. Llanigon, Maestorglwyd Barn (SO 214 374)

Felling date: Winter 1411/2

Rear Wall Plate 1411(18C): $t=$ 4.7, N/Ni 98/80, 1/p=190 [SWAN001]; window lintel 1408 (12 + 4NMC); cruck blade 1391 (6)

The barn at Maestorglwyd was originally a high-status hall house. See Miles et al. (this volume) for further details of the building and the dating.

(For images of this building, see Figures I-1 and I-2, p. xx.) 


\section{MONMOUTHSHIRE}

10. Cwmyoy, Llwyn Celyn. (SO 310 218)

(a) Solar

(b) Hall

(c) Inserted floor

(d) Back Kitchen

(e) Linking House (adjoining the barn)

(f) Beast House

(g) Lower Barn or Granary

Felling date: Winter 1418/9

Felling date: Winter 1420/1

Felling date: Winter 1695/6

Felling date: Winter 1695/6

Felling date: Winter 1695/6

Felling date: Winter 1688/9

Felling date: Spring 1843

(a) Principal rafter 1418(16C): $t=4.2, \mathrm{~N} / \mathrm{Ni}$ 50/50, 1/p=20 [SWAN002]; (b) Ceiling joists 1420(17C): $t=4.7$, N/Ni 57/57, 1/p=136 [SWAN003]; (c) Longitudinal beam 1695(24C): $t=4.86$, N/Ni 66/51, 1/p=1341 [SWAN005]; Mantel beam 1695(25C): $t=5.45$, N/Ni 119/74, 1/p >21k [SWAN008]; (d) Half beam 1668(1): $t=$ 4.83, N/Ni 62/55, 1/p=1484 [SWAN016]; Longitudinal beam 1644: $t=4.51$, N/Ni 78/79,1/p=564 [SWAN015]; (e) Purlin 1693(13): $t=4.49, \mathrm{~N} / \mathrm{Ni} 67 / 42,1 / \mathrm{p}>353$ [SWAN017]; Purlin 1695(11C): $t=4.38$, N/Ni 55/37, 1/p=245 [SWAN018]; (f) Beam 1688(18C): $t=5.98$, N/Ni 92/73,1/p>184k [SWAN025]; Beam 1688(11C): $t=$ 4.37, N/Ni 38/33, 1/p=142 [SWAN011]; Tiebeam 1688(26C): $t=6.05$, N/Ni 84/69, 1/p $>200 \mathrm{k}$ [SWAN023]; (g) Principal rafter 1837(13): $t=5.8$, N/Ni 45/43,

$1 / \mathrm{p}>2321$ [SWAN012]; Principal rafter 1842(11): $t=8.4, \mathrm{~N} / \mathrm{Ni} 44 / 40,1 / \mathrm{p}>1$ million [SWAN013]; Tiebeam 1842(141/4C): $t=6.1, \mathrm{~N} / \mathrm{Ni} 52 / 50,1 / \mathrm{p}=9372$ [SWAN014].

The main building failed to date initially through conventional ring-width dendrochronological analysis. Application of isotope-

dendrochronology and development of a phase chronology, enabled secure cross-dating of two of the longest samples of the primary phase, from the Solar wing (a) to winter 1418/19 and from the Hall range (b) to winter 1420/21. This dating was confirmed by ${ }^{14} \mathrm{C}$ analysis of both inner and outer parts of both samples (see Loader et al. 2019). The building is of exceptional quality, leading to the suggestion that it was perhaps built for the prior of Llanthony Priory, which owned the site until the Dissolution. It comprises a two-storey solar wing, attached to an open hall with three-bay double arch-braced roof and a spere truss; beyond the cross passage, doorways with ornamental heads lead to a buttery and pantry.

Samples from other parts of the complex also failed to date using ring-widths, many of the timbers having severe pollarding events. Isotope analysis has enabled a site/phase master to be constructed, that could be used to reliably date the individual timbers and phases. In 1696 the Hall was floored over and a fireplace installed (c). This included two longitudinal beams and joists with diminished haunches. Using timbers felled at the same time, a kitchen wing was added to the north of the cross passage (d). Again at the same time, as part of the farm building complex, the Linking House was added in the south-east angle of the threshing barn's porch (e). This building had a fireplace and hearth, and a small wall cupboard, all much altered over the centuries. Originally, it had a pitched roof supported on purlins, that was later converted to a mono-pitch roof. This date also provides a terminus ante quem date for the threshing barn, since the barn's construction must precede that of the Linking House.

The Beast House (f) is stone-built, of random coursed rubblestone, aligned end-on to the prevailing slope. One window retains its original frame in timber, of five un-glazed narrow lights with diamond mullions. The steeply pitched roof is of four bays with A-frame trusses supporting three tiers of trenched purlins and a ridge-piece. The latest phase dated (Spring 1843) is the lower barn, sometimes referred to as the granary (g). This 
long $1 \frac{1}{2}$ storey building abuts the Linking House to the south east of the Threshing Barn. It is thought originally to have been a cart shed with granary above.

This unusually thorough sampling was conducted in two phases as part of the Landmark Trust's restoration of Llwyn Celyn, with the support of the National Lottery Heritage Fund. Building information from Caroline Stanford; see also C. Stanford, Llwyn Celyn History Album (Landmark Trust, 2018). Available online at https://www.landmarktrust.org.uk/about-us/history-albums/\#L

$$
\text { (For an aerial view of this complex, see Figure I-10, p. xx.) }
$$

\section{NORTHERN IRELAND}

\section{COUNTY DOWN}

11. Portaferry, Portaferry Castle (J 593 508)

Felling date: After 1693

Lintel 1669: $t=6.1$, N/Ni 92/80, 1/p>40k [SWAN006].

Sample Q11972d was collected by David Brown and passed to Swansea University for isotopic analysis. The sample comprised 92 complete rings with a final degraded ring, but without sapwood or heartwood/sapwood boundary. Oxygen isotope dating of the first 80 annual growth rings produced a date of 1657. The addition of the unused rings produced a final year of 1669 (earlywood of 1670 present). Application of the Belfast sapwood estimate of $32+/-9$ years gives the terminus post quem date reported. This isotopic date also supports the correctness of a series of low tree-ring BP- $t$-values $(t=3.30-3.88)$ for the sample (D. Brown pers comm). 